\title{
CHARTING A COURSE \\ FOR THE FUTURE OF WOMEN'S HEALTH \\ IN THE UNITED STATES: CONCEPTS, FINDINGS AND RECOMMENDATIONS
}

\author{
Donna M. STROBINO, Holly GRASON, \\ and Cynthia MIN KOVITZ
}

TheWomen'sandChildren's Health PdigyCenter Department of Population andFamily Health Saienes

TheJdons Hodkins Schod of HygieneandPublicHealth, Baltimore, MD, USA.

\begin{abstract}
TheJHU Women'sandChildren's HelthPdigyCenter, withthefederal Matemal and Child Health Bureau, undatook a review of the health of womenin the United States and invited expets to devdop recommendations on helth polig, pro gams, practicesandrearch Therevievindudkel pubishedresench programreviens, and poligy reports on women's physical helth mental health and health behaviors, and on the ffeets of health services, systems and finaningon their health Based on trends in age thricbadkground, eduration, labor-forceparticipation, mamiageand dildbearingamongwamen, theresults of thereviens, and the expets' consultation, several recommendations weemadefor a forwardlookingagenda. They induded the neet 1) tofous broadyon women's hellth not just duringpregnangy, 2) for compre

* This paper has already been published in Social SaienceandMediane, special issue, vol. 54, no. 5, March 2002, p. 839-848.
\end{abstract}


hensive integatedprogamsandservices adkressinguomen'suniqueneeds 3) forinte gateel programs and services across thelifespen; 4) for better provider trainingabat women's uniqueheatth needs, the differential effets of partiailar problens on them and the consequeneses of dronichelt th problems hetedfore considared pimarily male problems 5) toediminatesoial podides that singeat women, partialarly pregant women, for punitiveadions; 6) topromtesoial podides that ensureeconomicseunity

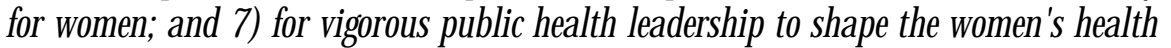
agenda, reogizingthesoial and eecnomiccontext of thir lives Thesoial andeo nomic trends ammg women in the United States and the reecmmendations for a wormen's helth agenda haverderanceto other dadoped countries as well.

Keyw ords: Womm's helth, Helth podig, United States, Soial and eannic trends, Multiplerdes, Lifespan

\section{Résumé}

LeJHU Women's and Children Helth PdigyCenter e leFedarl Matemal andChild Health Bureau ont procédéàun état des liex dela santédes fermes aux ÉtatsUnis \& ont invitédes expetsàfomiler des recommandationssur la pditique, les programmes dadion les pratiques et la rehedheen matièedesanté Ce invertairecaurelesrechechespubliés lesévluationsdeprogrammeselesrappatspditiquessurla santéphysiqued mentaledesfermss surlens compatementsàctégend, etsurlerd̂edes services desantéed del'arganisation è dufinanement deceseter. À partir des tendances dbsavés dhe les fermes en fontion del'âce, del'orignethnique, dunivesu dinstrution, del'adivitééconomique, delanuptialitéed dela fééndité faumies par l'inventaireet par les consultations d'expets, les autenrs présentert plut siers reecommandations saus la forme edun progammedadion par l'aveir. Elles

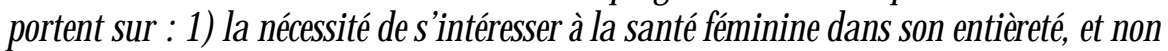
aux salles péiodes degrossesse; 2) la néessitédemettreen aure des programmes \& servicespodyalentse intégéśspar fairefaceaux besainsspéifiquesdesfermes; 3) la néessitédeprécir des programmes es sevicesintégés par tausles âges dela vie; 4) la néessitédunemilleureformation des agentsen cequi conemeles spéificités dela

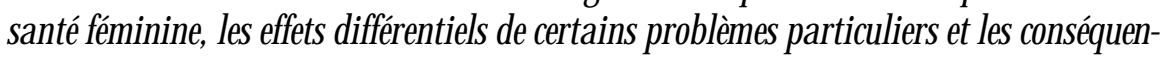
ces decataines maladies droniques considáéés jusquàpréét commedes prodènes essentiellement masalins; 5) la néeessitédenfinir aveclespolitiquessoiales qui stig matisentlesfermes en partialierlesfermesenceintes parlespénaliser; 6) la nées sitédencaragr les politiques sociales qui garantissent unebonneséeunitééconomique aux fermes; 7) et la néessitédefondar les progammes daadion en matièedesanté fémininesur un ensendle deprinipes d’aientation énegiques, en tenant comptedu 
contextesocial e économiquedanslequa viventlesfermes L'édutiondela situation soiale \& économique des fermes aux ÉtatsUnis \& les recommandations paur un programmedaction en matièedesantéfémininepanent sappliquer auss àdautres pays dédoppés

Mots-clés : Santédes fermes, Pditiquedesanté ÉtatsUnis, Tendanceséconamiques \& soiales, Rôles miltiples, Duréédevie

\section{Introduction}

The turn of the century offers an opportunity to assess the current state of the field of women's health in the United States and to make plans for the next century. As in other developed countries (Hayashi, 2000; Sundby, this volume), women's health has seen many changes during the century, particularly in the past thirty years, reflecting social, cultural and economic transitions in the lives of women. Recent trends in the social and economic status of women, especially their educational attainment, employment status, and choices about reproduction and family composition point to an increasingly complex social context influencing their health.

The dramatic changes in the lives of women in the United States at home and at work challenge the health field to expand its understanding of the meaning of women's health. Moreover, the philosophy of health care for women has evolved from a reproduction-centered medical model to one that increasingly describes women's health in terms of the totality of their experiences across the life span, including their expanded social and economic roles and the influence of culture, psychology, and social factors in other words, a biopsychosocial model of women's health. This view goes beyond recognizing biological differences to consider gender-based social and economic inequities that affect health. It also recognizes that health is more than the absence of disease or disability; it is the maintenance of psychological and social well-being as well as physical health. In this view, gender becomes a key variable in understanding social and medical forces that affect women's health, including their social roles, economic status, access to health resources, experiences of health and illness, and interactions with the health care system. 
In the last ten years, the field of women's health has been confronted by a host of new challenges and opportunities in the United States: a rapidly changing health care delivery system driven by cost containment and reduced public health expenditures; social welfare policy reforms that profoundly alter the lives of poor women and their children; continuing trends toward devolving responsibility for health and social programs from the federal government to states and from states to communities; and a resurgence of women's activism that has changed health and research priorities and policies. With these changes in perspective, this paper addresses the social and economic context of the lives of women, and its implications for policies, practices and programs related to women's health in the United States and in other developed countries, where appropriate.

The Women's and Children's Health Policy Center (WCHPC) at the Johns Hopkins University School of Public Health, in collaboration with the federal Maternal and Child Health Bureau (MCHB), undertook a review of the current state of women's and perinatal health in the United States and invited experts to help develop recommendations for a forward looking agenda ( $\mathrm{G}$ rason $\notin \mathrm{al} ., \mathrm{1999}$ ). The results of this review and a meeting of experts in women's and perinatal health form the basis for this paper. A key contribution of the initiative, referred to here as Charting a Course for Women's Health, lies in its public health orientation, one that seeks to address population health in the context of social, environmental, and behavioral factors.

In Charting a Course for Women's Health, two major questions were addressed: 1) in the next decade, how should the field of women's and perinatal health respond to emerging concerns resulting from shifts in the political, social and cultural landscape for women in the United States; and 2) how can the health of women be guaranteed. The WCHPC assessment of these questions included a comprehensive review of published research, program reviews and policy reports concerning women's physical health, mental health, and health behaviors and the effects of health services, systems, structures, organization and financing on women's health (G rason $\notin$ al., 1999, vol. II). The review topics for this assessment were selected based on: their timeliness in terms of current policy debates about women's health in the United States; amenability to intervention by public health; relevance to both women's and perinatal health; and amount of information available on the topic; topics for which considerable information was already available in the literature, 
such as chronic illnesses and cancer, were either not reviewed or only briefly reviewed. Literature specific to the health of the mother during pregnancy and her newborn was incorporated within the broader context of women's health during the childbearing years.

For the purposes of the review of the literature, the definition at the Fourth World Conference on Women in Beijing was used as a starting point and was further refined based on the work of Weisman (1997) to include three basic features: 1) consideration of health as a product of cultural, social and psychological factors as well as biology; 2) viewing women's health from a life-span and multi-role perspective; and 3) recognition that extension of the concept of health beyond the absence of disease requires health promotion and health maintenance strategies by the individual, the health community, and society.

At a working meeting sponsored by MCHB and WCHPC, women's and perinatal health professionals, policy makers and advocates identified the most pressing health concerns for women of reproductive age. D rawing upon the reviews of the literature, meeting participants identified changes that need to be made in health policy, services and systems in order to ensure continuous improvement in women's health. Following the meeting, additional feedback was obtained from the experts about recommended changes with regard to six areas related to women's health: social policies; surveillance and quality assurance; service availability, coordination, and organization; financing of health programs and services; health communication and education services; and development of workforce competency and capacity.

\section{Demographic and socioeconomic trends for American women}

Familiarity with recent social and demographic trends that affect women is essential for understanding the context of women's health in the United States and other developed countries. Social, economic, and political forces shape women's health by influencing trends in population characteristics, education and employment of women, reproduction, family composition and household economic status. Six major social and economic changes, important to understanding women's health in the United States today and in the future, are: aging of the female population; increased ethnic and racial diversity of the population; increasing labor force participation of women, particularly among women with children; 
delay in marriage and childbearing of women; a rise in female-headed single parent families; and continued economic disparities between men and women and racial and ethnic groups. These trends contribute to women's predisposition to chronic diseases, and influence health beliefs and behaviors and access to health care.

The U.S. female population has been and will increasingly be aging over the next fifty years. Since 1950, the number of women aged 65 or older tripled from 6.5 million in 1950 to over 20 million in 1998 (D ay, 1995). The United States Bureau of the Census estimates that by July 2020 this number will exceed 29 million and represent close to one-fifth of the total female population. Over 42 million women aged 65 years or older are projected to be living in the U.S. by 2050, accounting for 21 percent of the total female population (D ay, 1995). This rise is due primarily to the aging of the baby-boom population (born between 1946 and 1964), with some contribution from an increase in life expectancy for women.

A result of the aging of the female population is likely to be increasing numbers of women living longer with chronic illness and functional disabilities for which a greater proportion of the health care expenditures in the U.S. will be needed. Moreover, these women will increasingly be without partners due to earlier mortality of men, high divorce rates and rising proportions of women who choose not to marry. Women will have fewer children as well, resulting in less available family support for this aging population (U.S. Bureau of the Census, 1996).

At the same time, the U.S. female population has become and increasingly will be more ethnically diverse, particularly at ages at which women historically have their families. The rate of population growth is greatest for Asians, but the growth in numbers is greatest for Hispanic women, because the U.S. Hispanic population is considerably larger than the Asian population (U.S. Bureau of the Census, 1996). Ten percent of the female population is currently of Hispanic origin, but this figure is estimated to be 16 percent by 2020 and 24 percent by 2050 . The Asian female population is estimated to grow from 4 percent of the population in 1996 to 6 percent in 2020 and close to 9 percent in 2050. NonHispanic white women, who currently account for 73 percent of the female population, are projected to make up 60 percent of the population in 2030 and only 53 percent in 2050 (U.S. Bureau of the Census, 1996).

These changes in ethnic composition have important implications for the health of American women and their access to health care, par- 
ticularly with regard to allocation of health care services, outreach services to bring women into care, and cultural training of the health care work force. Financial and other barriers to health care utilization often prevent appropriate use of preventive services, such as mammograms, among minority women (Wyn $\notin \mathrm{al} ., 1996)$. Minority women also are at greater risk of a host of chronic and acute illnesses (Geronimus \& al., 1991; G eronimus and Bound, 1990; National Center for Health Statistics, 1990). The need for services that are culturally sensitive to the varied ethnic groups in the population will become increasingly important as well.

In the last half of the 20th century, there was a dramatic rise in the labor force participation of women in the United States. In 1950, about 30 percent of women aged 16 or older participated in the formal labor force. This percentage nearly doubled to 57 percent by 1990 and reached 59 percent in 1994 (Wagener \& al., 1997). The rise has been particularly marked for women with young children. Less than 40 percent of women with children under six worked in the formal labor force in 1975, whereas 65 percent did so in 1997. The respective figures for employed women with children aged 6-17 were 55 and 78 percent (Maternal and Child Health Bureau, 1998).

One reason for the higher rate of labor force participation of women with children is the variability in the rate among different age cohorts of women. While increases have occurred for all ages of American women, the labor force participation rate is almost double the rate at ages 20-24 for cohorts of women born in 1961-65 as compared with those born in 1926-30 (Figure 1). Moreover, while cohorts born before 1950 showed a drop in participation in their twenties and early thirties when women were caring for young children in their homes, no drop has been noted for more recent cohorts (Institute for Women's Policy Research, 1996). Sundby (this volume) reports that the current generation of Norwegian women started working before the birth of their children and have struggled to stay in the labor force. Japanese data (Hayashi, 2000), however, still show a drop in labor force participation for women of childbearing age, although the drop occurred at later ages in 1995 (at ages 30-34 years) than in 1975 (ages 25-29).

The rise in labor force participation has been accompanied by a rise in educational levels of women and a decrease in the gap between black and white women with regard to completion of secondary education. Although historically black women received less education than white women, the racial gap in high school completion has largely been erased; 
89 percent of white women and 87 percent of black women aged 25 or older in 1997 had completed high school education, compared with only 22 percent of white women and less than 10 percent of black women in 1940 (Adams and U.S. Bureau of the Census, 1995). D isparities still exist, however, for Hispanic women for whom only 65 percent aged 25 or older had completed high school education in 1997 (D ay and Curry, 1998).

Figure 1

Trends in labor force participation rates for women 1950-95,

by birth cohort

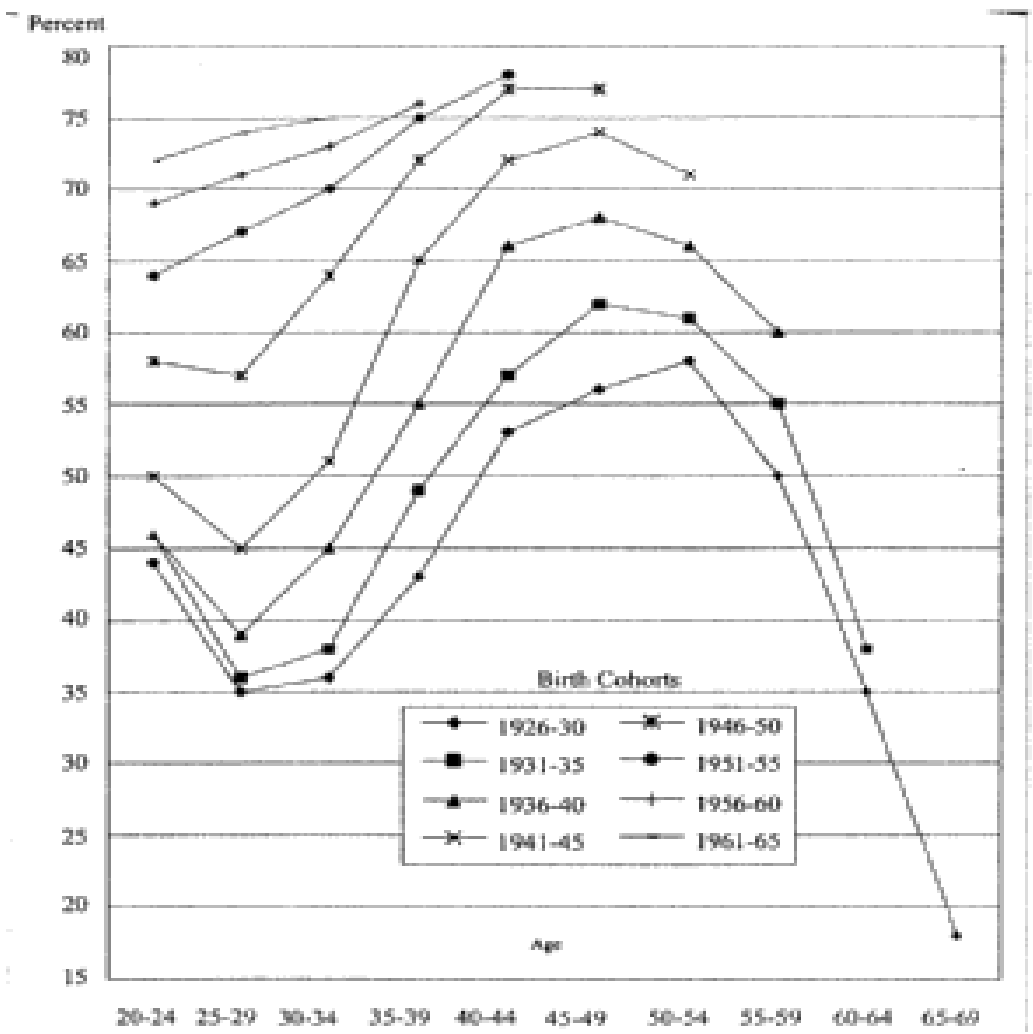


Although a gender gap in completion of a college education has historically favored men, this gap actually reversed in recent years; women are now slightly more likely to complete college than men. In 1970, women were only about two-thirds as likely to attain a bachelors degree as men but they were over 10 percent more likely to have attained one than men in 1997 (D ay and Curry, 1998). Hayashi (2000) notes that Japanese women's enrollment in college overtook that of men in the late 1980s and Sundby (this volume) reports increases in education completed by Norwegian women. Women in the United States as well as in other developed countries are now more literate than ever before and have greater options to pursue careers and to make choices about marriage and childbearing as well. The higher education of women is likely to lead to greater consciousness about their health as well.

Despite advances in education, increased labor force participation and a faster rate of growth in income than men, gaps in earnings for women persist relative to those for men. In 1998, U.S. women still earned

Figure 2

The female-male wage gap over the life cycle

(1998 median annual earnings by age)

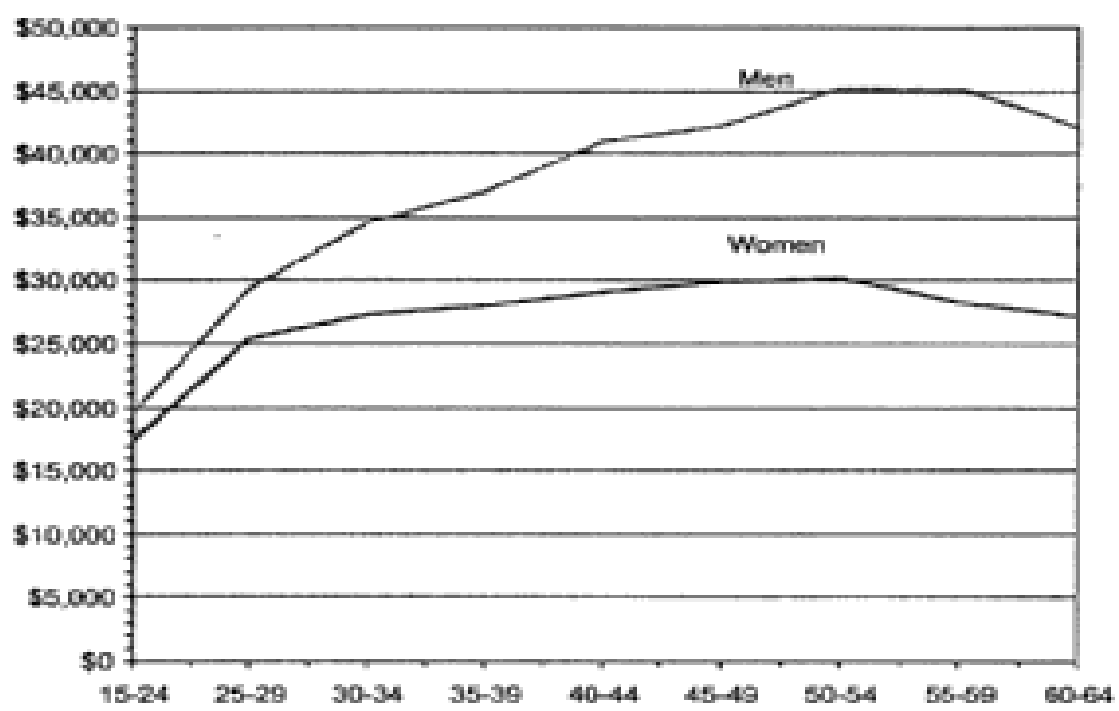


only 76 percent of men's median earnings, adjusted for education, and the gap in earnings increases as women age (Figure 2) (Bureau of Labor Statistics, 1999). A similar gap persists in wages between Japanese men and women (Hayashi, 2000). The recent increase in women's earnings in the United States, however, has been attributed to a decline in men's wages, rather than to a rise in women's earnings. A gap also is noted for black women in their earnings relative to white women (D ay and Curry, 1998).

Since the 1970s, there has been a decline in first births among women in their twenties, while the number and proportion of first births to U.S. women in their thirties has risen dramatically. The age-specific fertility rate for women 30-34 years rose from 52.3 births per 1,000 women in 1970 to 87.4 in 1998 (Ventura \& al., 2000). For women aged 35-39, the rate in 1998 was 37.4 and has nearly doubled since 1978 (19.0) (Ventura $\&$ al., 2000). Moreover, although the number of women having births at 40 or older is not large (84,809 in 1998), the fertility rate for this age group has nearly doubled since its low in 1981 (V entura $\notin a l ., 2000)$. A trend in increasing median age at first birth has also occurred in Norway among cohorts born in the 1950s and 1960s (Sundby, this volume).

The rise in the age at first birth is due in part to a rising age at marriage. The median age of marriage for American women rose from 20.8 in 1970 to 24.5 in 1994 (Saluter, 1996). Between 1970 and 1994, the proportion of women aged 30-34 who had not married tripled from 6 to 20 percent and it rose from 5 to 13 percent for women aged 35-39 (Saluter, 1996). Hayashi (2000) reported a similarly large increase in the percentage of unmarried women in Japan aged 25-29 and 30-34 years. At the same time, there has been an increase in the number of women who choose to remain childless. In 1994, there were 5.4 million American women who had no children and expected none in the future. Most of these women (4.1 million) had chosen voluntarily not to have children (Abma $\&$ al., 1997).

The delay in childbearing has implications for the health of women during pregnancy. Women who delay childbearing may have limited or later contact with the health care system, yet rates of chronic diseases increase with age as do maternal mortality rates (Atrash \&al., 1995; Berg eal., 1996; G eronimus and Bound, 1990). Moreover, with delayed childbearing, women in their thirties and forties are increasingly confronted with having the dual roles of simultaneously caring for young children and elderly parents (Menken, 1985). Women are considerably more likely 
than men to be caretakers of the terminally ill (72.1 percent in a recent study) (Emanuel $\&$ al., 1999), so that the responsibility for both their children and elderly parents falls disproportionately on their shoulders.

Concomitant with later marriage and childbearing has been a rise in single-parent households, the majority of which are headed by women (Saluter, 1996). This rise is due primarily to rising divorce rates, and secondarily to an increase in childbearing outside of marriage (Saluter, 1996). Although young women are more likely to have a child outside of marriage, the percentage of births to unmarried women has risen for all age groups (Ventura $\notin a l ., 2000)$. Black families (47 percent) are considerably more likely than white families (14 percent) to be maintained by women without a spouse present (U.S. Bureau of the Census, 1994).

Female-headed households are at a distinct economic disadvantage compared to households with male heads or married couple households. In 1997, the median family income of a female-headed household with children was $\$ 23,040$, compared to $\$ 36,634$ for male-headed households and $\$ 51,681$ for married-couple households (U.S. Bureau of the Census, 1998). The higher incomes of married couple households are due in part to both spouses working outside the home.

The poor economic status of female-headed families means that the women who head these families are likely to experience many of the same stressors related to multiple roles as their higher income counterparts, but have less resources in terms of money and spousal support to address these stressors. This may be one reason for their increased risk of chronic and acute illnesses and their decreased access to needed health services. Indeed, Khlat \& al. (2000) note that French women with children at home report poorer perceived health and more symptoms of malaise in the absence of a spouse to provide help and support.

\section{Policies, programs, and practices for improving women's health}

Recognizing the importance of the social and economic context for American women, several broad recommendations for health programs, practices and policies were made by the WCHPC in consultation with experts in the field. Many recommendations are similar to those made by the Commission on Women's Health in Norway, despite the greater benefits provided there for women and families (Sundby, this volume). 


\section{Broadening the focus beyond matemity care}

While childbearing is still an important event for the vast majority of women in the United States, focusing primarily on women's health during pregnancy and the childbearing years is far too narrow. Women perform many roles other than mother in their lifetime. These roles affect their health, which, in turn, may influence their ability to successfully fulfill their social roles, including, but not limited to, parenting. Women in the United States today spend on average more time in the work place over their life time than they do parenting dependent children. G iven the average number of 2.2 children expected by U.S. women in 1995 (Abma \& al., 1997), pregnancy and care of an infant occupy less than ten percent of a woman's adult life.

The narrow focus on pregnancy has rendered a fragmented approach to providing publicly funded insurance coverage to low income women in the United States. Coverage is provided primarily during pregnancy and the postpartum period, but not during the interconception period or after women stop childbearing. This coverage also emphasizes the health of the newborn, and the mother as the biologic vehicle whose health is important to primarily protect the fetus. Many low income women who have stopped childbearing, some because of their age and others by choice, are not covered in the U.S. through publicly funded insurance until they reach an age eligible for Medicare (usually age 62 at the earliest) (Collins $\& a \mathrm{l} ., 1994)$. This problem is particularly acute among women of color who are at increased risk in their 30s, 40s, and 50s of chronic illness, particularly hypertension and adult-onset diabetes (Geronimus \&al., 1991; National Center for Health Statistics, 1990).

Another constraint related to the historical focus on pregnancy is that assuring the general health of women prior to becoming pregnant is not a priority, despite its important effect on pregnancy outcomes and health in later years. Moreover, there is increasing evidence that preconception care, a form of well woman care that recently has been promoted as a fundamental component of pregnancy care, is important in reducing the risk of poor pregnancy outcomes, particularly those related to birth defects. For example, use of folic acid supplements prior to pregnancy and during the first trimester reduces the risk of neural tube defects (Mills \& al., 1996; Smithells \& al., 1981; Wald, 1995). Moreover, good glycemic control at the start of pregnancy for women with insulin dependent dia- 
betes reduces the risk of birth defects to levels similar to those for women without diabetes (Jack and Culpepper, 1990).

Evidence suggesting that women are choosing to delay childbearing and to remain voluntarily childless further highlights the need to shift the historic focus primarily on reproductive health to a more comprehensive approach to women's health care needs. This historic focus fails to identify the growing numbers of women who may not enter the health care system for childbearing related services, and whose health may be compromised in later years as a result.

Birn (1999) also recognizes the narrow focus on women's reproductive health historically taken in the International Health arena, particularly with regard to foundation funding of public health programs. A more holistic approach to women's health care must be taken to address the overall needs of women and the integration of services for them, regardless of their reproduction status. Birn argues that a revolutionary change must occur in the social fabric of countries in order to advance the health of men and women alike as well as social, economic and political equity for women.

\section{Women-centered care: addressing their multiple roles}

A second recommendation from Charting a Course is that women need comprehensive, integrated programs and services, including preventive services, that address their unique needs and circumstances. The fragmented nature of the U.S. health care system, unlike most other developed countries, contributes to women's inability to take advantage of the full range of services they need. Women often have multiple providers for pregnancy care, gynecologic health, well woman care, and treatment of chronic health conditions. Mental health services and substance abuse treatment are also often separate from preventive and medical services. The unique health needs of women are not only related to conditions for which they may be at greater risk, such as breast, ovarian and cervical cancer, or for which they experience greater morbidity and mortality, such as alcoholism, but also to the multiple social roles they assume (McD onough \&al., this volume).

The most poignant example of the need of the health care system to promote women-centered care that addresses their multiple roles and unique needs involves treatment for alcohol and drug abuse. A major 
barrier to accessing treatment for women who abuse drugs or alcohol is that relatively few in-patient programs permit children to accompany their mothers in treatment and few out-patient services provide child care while women are in treatment. Success in these programs is linked to a woman's success in fulfilling her roles of mother, wife and in the work place (National Women's Resource Center, 1997). These programs, which have historically treated a largely male population, are not equipped to address these needs. Recommendations for gender-sensitive care include interventions that are family centered, focus on the importance of relationships for women, and address their needs for skills building and enhancement of self-esteem (National Women's Resource Center, 1997). A more integrated approach linking substance abuse treatment with traditional providers of care for women would begin to address some of these barriers.

\section{Integrated health care across the life span}

The third recommendation addresses the need to integrate women's health services and programs across the life span, recognizing that events that occur earlier in a woman's life may have a profound effect on her subsequent health. Health, or lack thereof, builds decade to decade, generation to generation. There is increasing evidence that one's health status at birth and socioeconomic position during the formative years interact to affect a host of health conditions in adulthood (Arber and Cooper, 2000; Langley-Evans and Jackson, 1996). O ne example of such links is the effect of mother's birth weight on the birth weight of her offspring. These intergenerational effects on birth weight have been hypothesized to be one explanation for the higher rates of poor pregnancy outcomes among black women as compared to white women in the U.S. (Sanderson $\notin$ al., 1995).

Another example of the need to integrate health programs and services over the life span is the fact that smoking in the United States is a pediatric problem. The vast majority of smokers start between grades 6 and 9 (roughly ages 11 to 15), and few adopt smoking after age 20 (Centers for D isease Control and Prevention, 1996). Y et, the health ramifications of smoking are often recognized for women first with regard to the birth weight of their infants and later in relation to increased risk for conditions such as lung cancer, chronic obstructive pulmonary disease, 
and heart disease (Kristeller and Johnson, 1997; Scanlon \&al., 1995). Prevention of smoking must begin with school age children, as early as elementary school. Another example of early prevention is the use of calcium supplements during adolescence and the early adult years to help prevent osteoporosis, a condition which generally does not occur until at least four decades later (Haines \& al., 1992; Heaney, 1991).

As noted above, of particular concern is the lack of health insurance for many low income women in the United States during the time period after they stop childbearing and before they qualify for Medicare. Even if they are employed, many do not have access to health insurance because their employers do not provide coverage for them. For example, they often work part-time or for small companies that can not afford health insurance coverage for employees. This gap in coverage has long-term implications for the health of low income women as well as for the costs of health care, as preventive strategies are often not available for the groups most in need of them. Without adequate health insurance coverage, low income women are less likely than more advantaged women to age in good health.

\section{Training health professionals about women's needs}

A fourth recommendation relates to the need for better training of health care providers about women's health issues, including knowledge about the unique needs of women, the differential effects of particular problems such as alcohol abuse on women, and the consequences on women of certain chronic health problems like heart disease, which heretofore have been considered primarily problems of men. This latter concern is due largely to the exclusion of women from clinical trials of treatment modalities and medications because of fear of the consequences on the fetus among pregnant women (Kingdon, 1995). This lack of knowledge has not only resulted in inadequate attention to the major killers of women, but also to limited screening for illnesses and personal health behaviors. For example, medical residents in training are less likely to screen women for alco hol abuse than they are to screen men (D awson eal., 1992), despite the particularly deleterious effect of alcohol abuse on women (Allen and Feeney, 1997; Mishra \&al., 1989).

A major deficit in education of health care providers has been the limited attention to how the social context of women's lives affects their 
health. Examples of topics that need to be integrated into the curriculum of medical schools include the effect of stress related to the multiple roles of women, the importance to women of relationships with their partners and their children, the social and economic circumstances of low income women, particularly those living in households with no other adult present, and the importance of cultural sensitivity in providing services to women from varied ethnic backgrounds.

This recommendation also implies the need to train more women in medicine and promote them into decision-making positions. As increasing numbers of women are being trained as physicians in the United States, the needs of women are increasingly being integrated, at least into clinical training programs. Nevertheless, women still have not filled the ranks of faculty in medical schools, particularly at higher ranks and in leadership positions.

\section{Impact of punitive policies for women}

Social policies that single out women, particularly pregnant women, for punitive actions need to be eliminated. These policies are both explicit and implicit and most evident for low income and minority women, for example, with regard to criminal liability of pregnant women who report using illicit drugs during pregnancy. Women are singled out explicitly with regard to laws in some states requiring screening of all pregnant women for drug use and, when detected to be positive, their prosecution for child abuse. These laws juxtapose classic ethical principles by giving priority to beneficence for the newborn over the rights of the mother for autonomy. Implicitly, in states without mandatory screening, low income women or women of color are more likely to be screened for drug use than higher income white women and, if found to be positive, are more likely to be reported to child welfare authorities (Chasnoff $\&$ al., 1990).

\section{Impact of reforms on women's health}

The sixth recommendation involves the need to develop social policies that ensure economic security for women and continuous access to health care throughout their lifetime. The current climate of welfare reform in the United States has eliminated many public benefits for low 
income women, without also providing adequate resources for them to become economically independent. While welfare reform increases the likelihood that women on welfare will move into the labor force, they often can only secure jobs that pay a minimum wage and that do not provide health insurance as a benefit. These jobs often require limited skills, and allow little control by the employee. Stress related to lack of control and low substantive complexity, routinization, and repetitiveness of tasks on the job have been associated with poor psychological health (Elliot, 1996; G ecas and Seff, 1989; Staples \&al., 1984). The low wages of jobs many women will have to take is also a concem, as McD onough $A$ al. (this volume) note that health disparities among Canadian women were based on absolute social disadvantage.

Women's simultaneous roles as paid workers and care givers have sparked controversy as society grapples with issues related to comparable worth, gender discrimination in the workforce, child care and the division of household labor among adults. Some research indicates an association of employment with good health, as measured by self-esteem, perceived health, and physical functioning (Pugliesi, 1995; Ross and Mirowsky 1995; Verbrugge, 1985). On the other hand, excessively demanding jobs with low control and conflicting responsibilities are linked with poor health for example, job strain can exacerbate chronic conditions such as hypertension (Brett \&al., 1997). McD onough \&al. (this volume), nevertheless, found that paid work enhanced the health of Canadian women in spite of their experience with greater chronic stress.

The passage of federal legislation, entitled Temporary Assistance for Needy Families (TANF), to reform welfare in the United States also raises concerns about support services available to families with working mothers as well as job training needs for women who have not previously been employed. Indeed, a legacy of welfare reform may be that it increases the number of roles low income women perform by forcing them into employment without also providing them with adequate supports, such as affordable day care and flexible working hours. Social policies are needed to promote job training, life skills building and literacy, and which are accompanied by affordable health insurance and health care.

A significant number of women may not be able to adapt to the absence of cash benefits, such as women with mental illnesses or with other problems that make them unemployable; their ultimate fate is unknown. A population that will be highly affected by welfare reform is immigrant 
women, whether or not they have legally or illegally entered in the United States. Benefits to this population, including Medicaid, have been abolished at the Federal level and are available only if states choose to provide them.

\section{The importance of public health}

The final recommendation concerns the importance of public health in moving the women's health agenda forward in the United States and in other developed countries because of its attention to population-based needs of women and its traditional emphasis on multidisciplinary and multiple systems strategies to address the social and economic contexts of women lives. Emphasis on the role of social and economic conditions in determining health date back in the United States to the origins of the Children's Bureau in the early 20th century, although the focus initially was largely on the effect of these conditions on the mother's health and, in turn, the health of her newborn. Fundamental to improving the health of the population is public health's long-standing orientation to social equity, as well as to the perspective that population health is related to social, environmental and behavioral factors (Krieger and Birn, 1998).

Public health is playing a major role in the United States at the national level in the formation of a number of offices related to research and policy on women's health. In the early 1990s, the O ffice of Research on Women's Health (1990) was created within the National Institutes of Health, a D eputy Assistant Secretary for Women's Health (1993) was appointed and the Public Health Service's O ffice on Women's Health (1991) and the Office of Women's Health Services within the Substance Abuse and Mental Health Services Administration (1992) were established. Since then, six additional units focused on women's health have been established within the Health Resources Administration, the Centers for D isease Control and Prevention, and the Food and Drug Administration. These units function alongside two others within the D epartment of Health and Human Services (D HHS) that have established roles in developing policy and administering programs for women

the Maternal and Child Health Bureau and the O ffice of Population Affairs. Beyond D HHS, the D epartments of Labor, Justice and D efense have created organizational loci and initiatives related to the health and 
well-being of women. In 1995, the White House established an O ffice for Women's Initiatives and O utreach.

D espite this attention, the field of public health in the U.S. is challenged by ever diminishing resources, marginalization in national public policy debates related to health and increasingly limited control of data and analysis. Moreover, intense political debate about women's rights, particularly with respect to reproductive health, equitable access to economic resources, and women's role in childbearing, dramatically complicates public health action on behalf of women.

\section{Conclusions}

D espite significant gains in recent years in narrowing the gaps in social indicators for men and women and for women of different racial and ethnic backgrounds, disparities persist in relation to burden of illness, educational attainment, employment and earnings. Improving the social climate that influences women's health means addressing these fundamental disparities. Understanding these differences and their implications should drive the design, implementation, and evaluation of policies and programs aimed at improving the health of women in the United States, and other developed countries as well.

Key approaches needed to improve women's health include the notions that health builds or diminishes over decades of life, and that prevention needs to begin early with continued vigilance throughout women's life span. An exclusive focus on pregnancy and maternal roles in policy development has led to missed opportunities, particularly with regard to assuring the health of women prior to beginning childbearing and from the time they stop childbearing until they reach old age. Comprehensiveness and integration of health efforts are key to promoting the health of women. Finally, health policies must build on a base of social policies that ensure economic security for women and that avoid singling them out for punitive actions.

Many groups influence women's health and are concerned with their well-being. Public health entities have the historical mandate and potential capacity, perspective and knowledge to assure the wellness of all women through partnerships and science. Today's challenge is to rekindle the mandate, infused with a more appropriate share of the political attention and resources available for women's health care in the United States. 


\section{References}

Abma, J. C., Chandra, A., Mosher, W. D., Peterson, L. S., and Piccinino, L. J. (1997), "Fertility, family planning, and women's health: New data from the $1995 \mathrm{Na}-$ tional Survey of Family G rowth", Vital andHealthStatistics vol. 23, no. 19, p. 1-114.

AdAMS, A., U.S. BuREAU OF THE CEnsus (1995), "Educational attainment. Population profile of the U.S." , CumentPpulation Reports

ALLEN, K. M., and FEENEY, E. (1997), "Alcohol and other drug use, abuse, and dependence”, in: K. M. Allen and J. M. Phillips, eds., Women's HealthAcross theLifespan: A ComprehensivePespetive, Philadelphia, PA, Lippincott, p. 256-288.

ARBER, S., and COOPER, H. (2000), "G ender and inequalities in health across the lifecourse", in: E. Annahdale and K. Hunt, eds., GenderInequalitiesinHealth Buckingham, O pen University Press, p. 123-147.

Atrash, H. K., AleXANDER, S., and BerG, C. J. (1995), "Maternal mortality in developed countries: Not just a concern of the past", ObstericsandGynedogy, vol. 86, no. 4, p. $700-705$.

Berg, C. J., A trash, H. K., Ko onin, L. M., and TuCKer, M. (1996), "Pregnancy-related mortality in the United States, 1987-1990", Obsteris and Gynedogy, vol. 88, no. 2, p. 161-167.

BIRN, A . (1999), "Skirting the issue: Women and international health in historical perspective", AmericanJaumal of PublicHelth vol. 89, no. 3, p. 399-407.

Brett, K. M., Stro GAtZ, D . S., and SAVITZ, D. A. (1997), "Employment, job strain, and preterm delivery among women in North Carolina”, AmericanJaumal ofPublicHęlth vol. 87, no. 2, p. 199-204.

BUREAU OF LABOR STATISTICS (1999), Highights of Women's Eamings in 1998 (Report \#928), U.S. D epartment of Labor.

Centers for Disease Control and Prevention (1996), "Tobacco use and usual source of cigarettes among high school students United States, 1995", MMWR, vol. 45, p. 413-418.

CHASNOFF, I. J., LANDRESS, H. J., and BARRETT, M. E. (1990), "The prevalence of illicitdrug or alco hol use during pregnancy and discrepancies in mandatory reporting in Pinellas County, Florida", TheNewEngandJaumal ofMediane, vol. 322, no. 17, p. 12021206.

Collins, K. S., Rowland, D ., SAlganicoff, A., and CHAit, E. (1994), Assessingand ImprovingWomen's Health A Women's HealthRepart of theWomen'sRescenchandEducation Institute(WREI), Washington, D C, Women's Research and Education Institute.

Dawson, N. V., D AdheEch, G., Speroff, T., Smith, R. L., and Schubert, D. S. P. (1992), "The effect of patient gender on the prevalence and recognition of alcoholism on a general medicine inpatient service", Jaumal of Geneal Intemal Medíne, vol. 7, p. 3845.

Day, J. C., and U.S. Bureau of the Census (1995), "Population projections of the United States by age, sex, race, and Hispanic origin: 1995 to 2050", Current Population Reparts

D AY, J., CURRY, A., and U.S. BuREAu OF THE CEnsus (1998), “Educational attainment in the United States: March 1997", Current PopulationReparts

ELLIOT, M. (1996), "Impact of work, family and welfare receipt on women's self-esteem in young adulthood", Social PsydhdogyQuartedy, vol. 39, p. 80-95. 
Emanuel, E. J., Fairclough, D. L., Slutsman, J., Alpert, H., Baldwin, D., and EMANUEL, L. L. (1999), "Assistance from family members, friends, paid caregivers, and volunteers in the care of terminally ill patients", TheNewEngandJaumal ofMeedicie, vol. 341, no. 13, p. 956-963.

GECAS, V., and SEFF, M. (1989), "Social class, occupational conditions, and self-esteem”, Soidogial Pespeetives vol. 32, p. 353-364.

G ERONIMUS, A. T. (1996), "Black/ White differences in the relationship of maternal age to birthweight: A population-based test of the weathering hypothesis", Scial Scienceand Mediane, vol. 42, no. 4, p. 589-597.

GERONIMUS, A. T., and BOUND, J. (1990), “Black/ White differences in women's reproductive-related health status: Evidence from vital statistics", Demgraphy, vol. 27, no. 3, p. 457-466.

Geronimus, A. T., Anderson, H. F., and Bound, J. (1991), “Differences in hypertension prevalence among U.S. black and white women of childbearing age", PublicHealth Reparts vol. 106, p. 393-399.

G RASO N, H. A., HUTCHINS, J. E., and Silver, G. B., eds. (1999), Chartinga Caurseforthe FutureofWomen'sandPeinatal Helth V dumeI: Concepts, Findings, andRecommendations V dumeII: ReviewofKeyIssues Baltimore, MD , Women's and Children's Health Policy Center.

Haines, P. S., Hungerfo RD, D. W., Po PKin, B. M., and G UILKey, D . K. (1992), "Eating patterns and energy and nutrient intakes of U.S. women", Jamal of theAmerican DieteicAssoiation vol. 92, no. 6, p. 698-704.

HAYASHI, K. (2000), "Women's socio-economic position and health", Paper presented at the CICRED meeting Social and EconamicPatteming of HealthAmongWomm Tunis.

HEANEY, R. P. (1991), "Effect of calcium on skeletal development, bone loss, and risk of fractures", AmericanJaumal of Mediane vol. 91, no. 5B, p. 23s-28s.

INSTITUTE FOR WOMEN'S POLICY RESEARCH (1996), TheStatus of Womm in theStates Washington, DC., Author.

JACK, B., and CUlPePPer, L. (1990), "Preconception care”, in: I. R. Merkatz and J. E. Thompson, eds., NewPespeetives on Prenatal Care, New Y ork, Elsevier.

KhLAT, M., SERMET, C., and LE PAPE, A. (2000), "Women's health in relation with their family and work roles: France in the early 1990s", Social Saienceand Mediane, vol. 50, no. 12 , p. $1807-1825$.

Kingd 0 N, J. W. (1995), Agendas, Altematives, andPublicPdicies $2^{\text {nd }}$ ed., New Y ork, Harper Collins.

KRIEGER, N., and BIRN, A. (1998), "A vision of social injustice as the foundation of public health: Commemorating 150 years of the spirit of 1848", AmericanJaumal of Public Health vol. 88, no. 11, p. 1603-1605.

KRISTEller, J. L., and JoHnSO N, T. J. (1997), “Smoking effects and cessation”, in: J. Rosenfeld, ed., Women's HealthinPrimaryCare, Baltimore, MD , Williams and Wilkins, p. 93-116.

LANG LEY-EVANS, S., and JACK SON, A. (1996), "Intrauterine programming of hypertension: Nutrient-hormone interactions", Nutrition Rexiens vol. 54, no. 6, p. 163-169.

Maternal AND Child Health BuREAU (1998), Child Helth USA, 1996-1997, U.S. D epartment of Health and Human Services.

Menken, J. L. (1985), “Age and fertility: How late can you wait?” Demogaphy, vol. 22, no. 4, p. 469-483. 
Mills, J. L., SCotT, J. M., Kirke, P. N., McPartlin, J. M., Conley, M. R., Weir, D. G., MOLLOY, A. M., and LEE, Y.J. (1996), "Homocysteine and neural tube defects", Jamal of Nutrition vol. 126, p. 756S-760S.

Mishra, L., SHARMA, S., PotTER, J.J., and MeZey, E. (1989), "More rapid elimination of alcohol in women as compared to their male siblings", Alchdism Clinical andExpeimetal Reserch vol. 13, no. 6, p. 752-754.

National Center for Health Statistics (1990), "Health of black and white Americans, 1985-1987", Vital and Hellth Statistics, Series 10, vol. 171, p. 9-11.

National Wo men's Reso urce Center (1997), A Reason for Hope SubstanceAbuse Treatmet DuningPregnany HasLongTemBenfits Alexandria, VA, Author.

PUG LIESI, K. (1995), "Work and well being: Gender differences in the psychological consequences of employment", Joumal of Helthand Soial Behaviar, vol. 36, no. 1, p. 57-71.

Ross, C., and MirowSKY, J. (1995), "D oes employment affect health?" Jarmal of Helth and Social Behavior, vol. 36, p. 230-243.

SALUTER, A. F., and U.S. BuREAu OF THE Census (1996), "Marital status and living arrangements: March 1994", Cumet PopulationRepats

SAND ERSON, M., EMANUEL, I., and HOLT, V. (1995), "The intergenerational relationship between mother's birthweight, infant birthweight and infant mortality in black and white mothers", PaediatricandPeinatal Epidemidogy, vol. 9, p. 391-405.

SCANLON, E. F., SUH, O., MurThy, S. M., MetTlin, C., Reid, S. E., and Cummings, K. M. (1995), "Influence of smoking on the development of lung metastases from breast cancer", Cancer, vol. 75, p. 2693-2699.

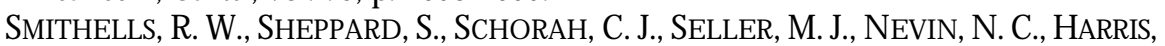
R., READ, A. P., and FIELDING, D. W. (1981), "Apparent prevention of neural tube defects by periconceptual vitamin supplementation", Arhives of Disesein Childhood, vol. 56, p. 911-918.

StAPLeS, C., SCWALBE, M., and GeCAS, V. (1984), "Social class, occupational conditions, and efficacy-based self-esteem", Soidogical Pespetives vol. 2, p. 85-109.

U.S. BUREAU OF THE CENSUS (1996), "Population projections of the United States by age, sex, race and Hispanic origin: 1995 to 2050", Cumet Population Repats

U.S. BuREAU OF THE Census (1998), "Money income in the United States: 1997 (with separate data on valuation of noncash benefits)", Current Population Repats

U.S. BuREAU OF THE CENSUS, and STATISTICAL BRIEF (1994), Whos MindingtheKids? U.S. Government Printing Office.

Ventura, S. J., Martin, J. A., Curtin, S. C., Mathews, T.J., and Park, M. M. (2000), "Births: Final data for 1998", National Vital Statistics Repat, vol. 47, no. 18, p. 1-96.

Verbrug Ge, L. M. (1985), "Gender and health: An update on hypothesis and evidence", Joumal of Hẹlth and Soial Behavio, vol. 26, p. 156-182.

WAGENER, D. K., WALSTEDT, J., JeNKINS, L., BURNETT, C., LALICH, N., and FINGERHUT, M. (1997), "Women: Work and health", Vital andHelth Statistics vol. 3, no. 31, p. 1-16.

WALD, N. J. (1995), "Folic acid and the prevention of neural tube defects: A population strategy is needed", BMy, vol. 310, p. 1019-1020.

WEISMAN, C. (1997), "Changing definition of women's health: Implications for health care and policy", Matemal andChildHealthJaumal, vol. 1, no. 3, p. 179-189.

WYN, R., BROWN, E. R., and Y U, H. (1996), "Women's use of preventive health services", in: M. M. Falik and K. S. Collins, eds., Women's Health TheCommmwelthFundSurvey, Baltimore, MD , Johns Hopkins University Press, p. 49-75. 